\title{
Impact of Fire on Mechanical Properties of Lightweight Bricks Containing Calcium Carbide Residue
}

\author{
Cut Rahmawati* ${ }^{\mathrm{a} *}$, Meliyana ${ }^{\mathrm{a}}$, Ibnu Thufail ${ }^{\mathrm{a}}$, Muhtadin $^{\mathrm{b}}$, Muhammad Faisal ${ }^{\mathrm{b}}$ \\ ${ }^{a}$ Department of Civil Engineering, Universitas Abulyatama, Aceh Besar, 23372 , Indonesia. \\ ${ }^{b}$ Department of Mechanical Engineering, Universitas Abulyatama, Aceh Besar, 23372, Indonesia. \\ *corresponding author: cutrahmawati@abulyatama.ac.id
}

\section{ARTICLE INFO}

Article history:

Accepted

\section{Keywords:}

Calcium carbide residue

lightweight bricks

fire

mechanical properties

\section{ABSTRACT}

Calcium carbide residue is an unutilized by-product. It contains high calcium and can be used to produce cementitious. The variation of Calcium carbide residue used is $0 \%, 5 \%$, and $15 \%$. This study focused on the reduction of the cement used and lightweight bricks resistance toward the fire condition. Moreover, the tests were carried out by examining the compressive strength before and after lightweight bricks burned, X-ray fluorescence (XRF), Scanning Electron Microscope (SEM), and Fourier-Transform Infrared Spectroscopy (FTIR). The result showed a decrease of compressive strength on $10 \%$ and $15 \%$ carbide variation. At the combustion temperature of $250{ }^{\circ} \mathrm{C}$, microcracking occurred at $0 \%$ and 5\% carbide specimens, while not only cracking but also spalling and crazing were at the specimens with $10 \%$ carbide. The $5 \%$ variation of calcium carbide residue can increase the compressive strength and endurance at $250{ }^{\circ} \mathrm{C}$. At the higher temperature, the compressive strength was decreased, and the material was damaged. IR-spectroscopy test results showed that $5 \%$ carbide composition achieved the highest compressive strength because the amount of $\mathrm{H}_{2} \mathrm{O}_{2}$ used reacts with $\mathrm{CaO}$.

Copyright (C) 2020 Politeknik Aceh Selatan. All rights reserved.

\section{Introduction}

Calcium carbide $\left(\mathrm{CaC}_{2}\right)$ is a renewable source of acetylene because of its active triple bonds and terminal protons, which plays an important role in organic synthesis. Solid $\mathrm{CaC}_{2}$ has several advantages over acetylene gas, including ease of handling, convenient storage, and transport [1]. $\mathrm{CaC}_{2}$ is thought to be a safer and more convenient source of acetylene. Carbide residue production is described in the following equation [2]:

$$
\mathrm{CaC}_{2}+2 \mathrm{H}_{2} \mathrm{O} \longrightarrow \mathrm{C}_{2} \mathrm{H}_{2}+\mathrm{Ca}(\mathrm{OH})_{2}
$$

Calcium carbide consists of calcium hydroxide, $\mathrm{Ca}(\mathrm{OH})_{2}$, and obtained in slurry form. Calcium Carbide Residue (CCR) is wasted and unutilized material. It is also used to produce a cementitious material [3].

CCR leads to serious environmental problems due to its alkalinity and should be appropriately disposed of. Most research concerned about the severe environmental pollution caused by large CCR dumps and suggested the utilization of CCR for construction material, which will be more environmentally friendly [4]. The carbide waste utilization as a lightweight brick material will significantly help preserve the environment through the Waste Co-Processing program. Waste CoProcessing is the utilization of industrial waste for other industries [5][6]. Problems related to environmental sustainability, reducing cement as a construction material, and the importance of lightweight bricks resistance encouraged us to research the carbide waste addition to the lightweight 
bricks to increase the durability. Durability is the material's ability to last longer from the influences of both within the material itself and outside [7][8]. The lightweight bricks are widely used in high rise buildings because they can reduce the construction burden. Moreover, lightweight bricks can make time processing faster because of their broader and thinner shape and also reduce transportation costs.

The previous studies about the fire in construction were conducted by [9][10][11]. The result showed that the explosive spalling occurred on the concrete's surface, which was burnt at $200^{\circ}-325^{\circ} \mathrm{C}$, while the fire above 400 to $600^{\circ} \mathrm{C}$ decreased the compressive strength. The addition of fibres did not significantly influence the fire resistance of the concrete [12]. Most of the researches on fire used the furnace to elevated temperature. The use of a furnace cannot reflect the real situation of fire. The mechanical properties of lightweight bricks containing calcium carbide residue are subjected to a real fire. This research aims to study the impact of fire on the mechanical properties of lightweight brick containing CCR. The results greatly benefit the understanding and future applications of the materials.

\section{Material and methods}

\subsection{Material}

Materials used in this study consisted of CCR, Portland cement Type I, river sand passing sieve No. 16, and retaining on sieve No. 100, water, and foaming agent. CCR was from the local welding industry, taken in the dry form, and sun-dried for 2-3 days. After being sun-dried, its moisture was less than 3\%. The chemical compositions of CCR were determined by X-ray Fluorescence analysis, and the results are shown in Table 1 . It was found that the major chemical constituents of $\mathrm{CCR}$ were $\mathrm{CaO}$ $(61.30 \%)$. CCR contained $\mathrm{Ca}(\mathrm{OH})_{2}$, which decomposed into $\mathrm{CaO}$ and $\mathrm{H}_{2} \mathrm{O}$ at approximately $550^{\circ} \mathrm{C}$. Particle size distributions of CCR can be seen in Fig. 1.

Table 1. Chemical compositions of calcium carbide residue (CCR)

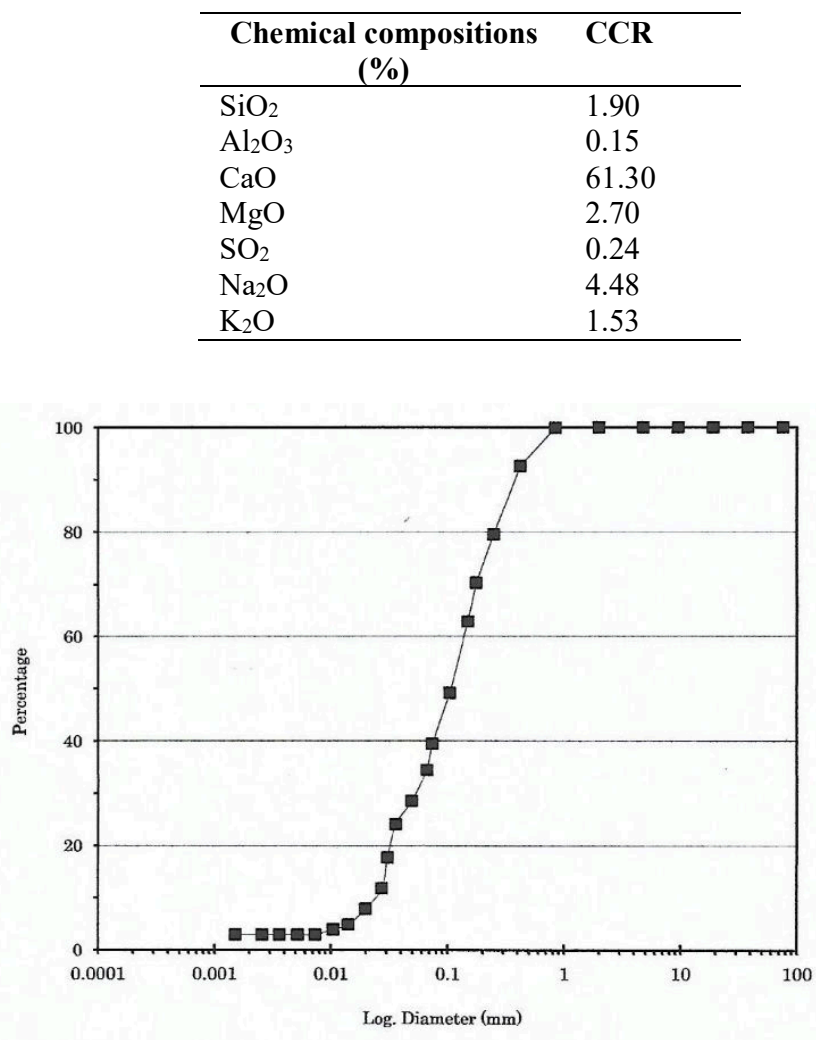

Figure. 1. The particle size distribution of CCR 
Portland pozzolana cement used in this study fulfils the requirement of ASTM C150-92 [13]. The sand used as the local sand. Besides, the foaming agent used was the factory-made with a density of 40 $\mathrm{kg} / \mathrm{m} 3$. To produce the foam, the ratio of foaming agent and water were $1: 40$. This foaming agent was diluted using a generator to form gas foam [14] [15]. The physical and chemical properties of CCR and fine aggregate are presented in Table 2.

Table 2. Physical properties of CCR and fine aggregate.

\begin{tabular}{lll}
\hline Properties & CCR & Fine Aggregate \\
\hline Specific Gravity & 2.29 & 2.64 \\
Water Absorption & $2.42 \%$ & $2.0 \%$ \\
\hline
\end{tabular}

\subsection{Mix Proportioning}

The weight of cement and water is determined from a water-cement ratio of 0.5 . The variation of carbide waste added to the lightweight brick mix was $5 \%, 10 \%$, and $15 \%$ by cement weight. Lightweight brick was also made with no mixture of carbide waste $(0 \%)$ as a control. Table 3 presents the mixture proportions of lightweight brick by packing density approach.

Table 3. Mix proportion Lightweight Brick containing CCR $\left(1 \mathrm{~m}^{3}\right)$

\begin{tabular}{ccccccc}
\hline Code & $\begin{array}{c}\text { CCR concentration } \\
(\%)\end{array}$ & $\begin{array}{c}\text { Cement } \\
(\mathbf{k g})\end{array}$ & $\begin{array}{c}\text { Sand } \\
(\mathbf{k g})\end{array}$ & $\begin{array}{c}\text { Water } \\
(\mathbf{l})\end{array}$ & $\begin{array}{c}\text { Foam } \\
(\mathbf{l})\end{array}$ & $\begin{array}{c}\text { CCR } \\
(\mathbf{k g})\end{array}$ \\
\hline CCR 0 & 0 & 320 & 320 & 160 & 613 & 0 \\
CCR 5 & 5 & 288 & 320 & 160 & 613 & 14.4 \\
CCR 10 & 10 & 272 & 320 & 160 & 613 & 27.2 \\
CCR 15 & 15 & 256 & 320 & 160 & 613 & 38.4 \\
\hline
\end{tabular}

Note: Mix designated by packing density approach $\left(600-800 \mathrm{~kg} / \mathrm{cm}^{2}\right)$.

\subsection{Casting of specimens}

$100 \times 100 \times 100 \mathrm{~mm}$ cubes were cast to determine the test specimen's compressive strength. All the specimens were de-moulded at the age of $24 \pm 1$ hours and were cures in the water tank at room temperature. The compressive strength testing was performed when the specimen was 28 days old as ASTM C-67 [16].

\subsection{Time-Temperature Curve}

The gas-burning furnace used in this study (a diameter of $430 \mathrm{~mm}$ and a height of $670 \mathrm{~mm}$ ) is shown in fig 2. A thermocouple measured the furnace's temperature, and the maximum temperature was $800^{\circ} \mathrm{C}$. Also, the gas-burning furnace temperature was regulated to follow the ISO curve [17]. Fig.3 shows the temperature-time curve of the gas-burning furnace. The specimens were burned for 30 minutes, and when the temperature reached $250^{\circ} \mathrm{C}$ and $400^{\circ} \mathrm{C}$, they were lifted to be tested for the compressive strength and microstructure.
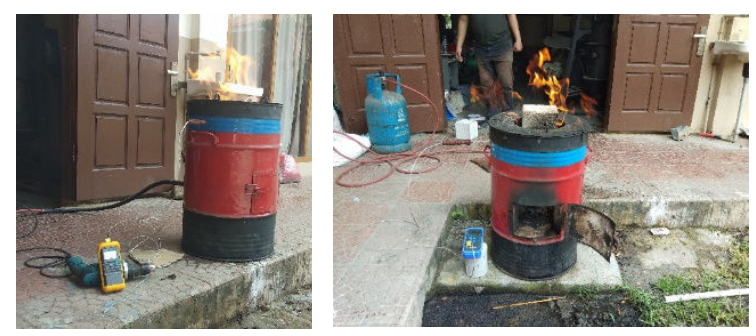
Figure 2. Gas burning furnace

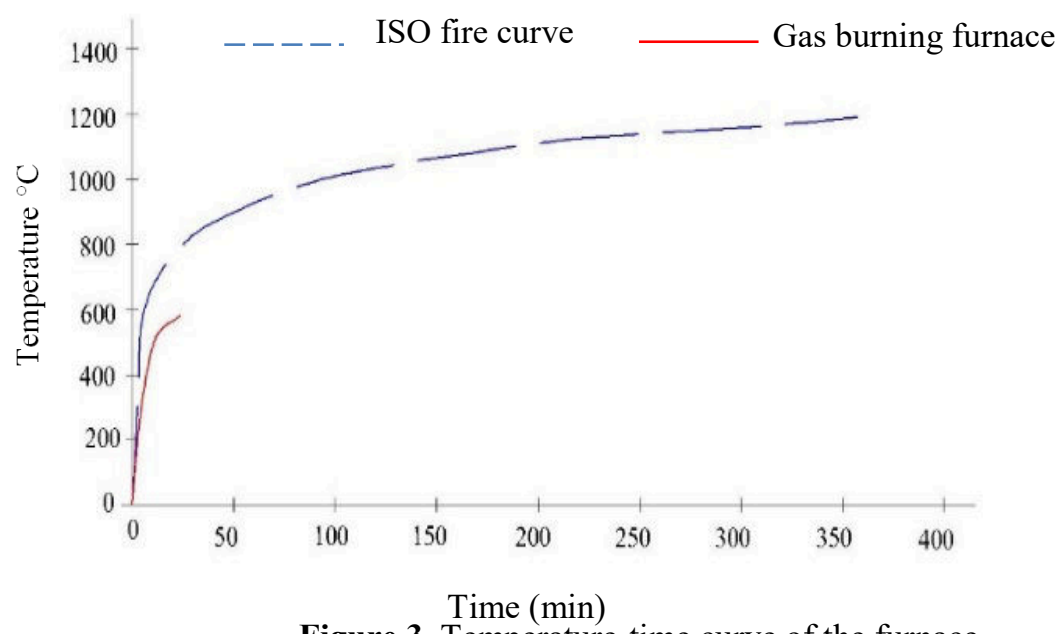

Figure 3. Temperature-time curve of the furnace

\section{Results and Discussion}

\subsection{Decreased compressive strength due to fire}

Table.4 and Fiq. 4 show the increase of the compressive strength in lightweight bricks with a concentration of 5\% CCR because cement can bind the carbide and affect the compressive strength. At the $10 \%$ carbide, the compressive strength was decreased due to the number of air bubbles in the sample. The addition of CCR increased foaming agents to keep lightweight bricks to remain at the planned volume weight, i.e., $800-1,000 \mathrm{~kg} / \mathrm{cm}^{3}$. Also, the addition of foaming agents led to more air pores, and lightweight bricks became brittle. This condition continued until the addition of $15 \%$ carbide.

Calcium and silica determine the concrete strength due to the decomposition when heating at high temperatures [18][19]. As a result of the decomposition in the lightweight bricks, there was a very drastic decrease in concrete's compressive strength. The chemical decomposition of lightweight bricks at high temperatures also increased the concrete porosity level caused by a product of a fire is the evaporation of a certain amount of water $\left(\mathrm{H}_{2} \mathrm{O}\right)$. Hence, some water molecules are released, and finally, the compressive strength of the concrete decreases.

Table 4. Decreased compressive strength of lightweight bricks due to fire

\begin{tabular}{cccc}
\hline $\begin{array}{c}\text { CCR concentration } \\
(\%)\end{array}$ & $\begin{array}{c}\text { Compressive strength } \\
\text { at ambient temp. (MPa) }\end{array}$ & $\begin{array}{c}\text { Compressive strength } \\
\text { at } \mathbf{2 5 0} \mathbf{\circ}^{\circ} \mathbf{C}(\mathbf{M P a})\end{array}$ & $\begin{array}{c}\text { Compressive strength } \\
\text { at } \mathbf{4 0 0}{ }^{\circ} \mathbf{C}(\mathbf{M P a})\end{array}$ \\
\hline 0 & 2.06 & 1.59 & 1.17 \\
5 & 2.33 & 1.90 & 1.60 \\
10 & 1.13 & 0.95 & - \\
15 & 0.96 & - & - \\
\hline
\end{tabular}




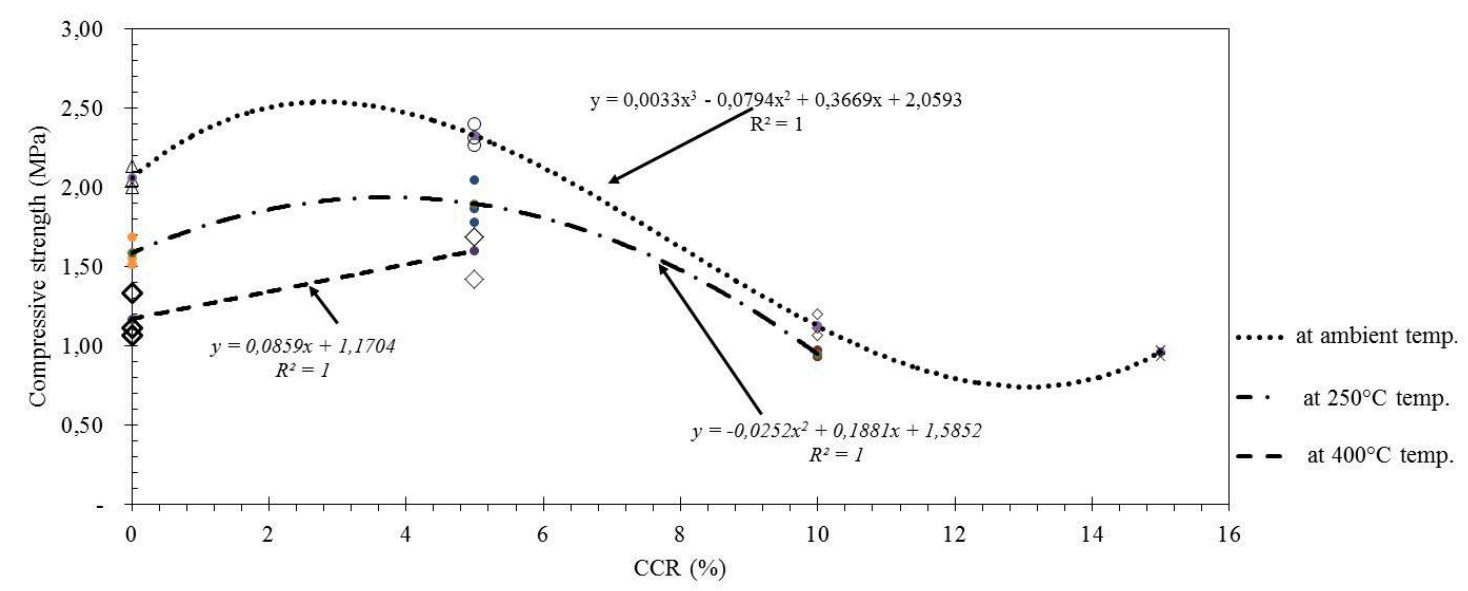

Figure 4. Decreased compressive strength of lightweight bricks due to fire at the temperature of $250^{\circ} \mathrm{C}$ and $400^{\circ} \mathrm{C}$

The decreased compressive strength, shown in Table.4 and Fiq.4, is due to calcium hydroxide $\left(\mathrm{Ca}(\mathrm{OH})_{2}\right)$ changing its composition into calcium oxide $(\mathrm{CaO})$, which has no strength. At high temperatures, the function of cement as a binder slowly disappears, resulting in a significant loss of concrete strength [20] [21]. Other causes are due to the damage to the cement hydration bond with coarse aggregate (split) and fine aggregate (sand) because the water that helps the bond is reduced. Finally, the strength of the concrete sample decreases and causes structural failure. The increase in the amount of vapour pressure in the lightweight brick pores is due to explosive spalling, a portion of the concrete segment detached from the surface. This portion occurs in lightweight bricks at $400^{\circ} \mathrm{C}$. At temperature above $400^{\circ} \mathrm{C}$, the lightweight bricks become very weak and brittle.

\subsection{Visual observations after exposure to fire}

The specimens were burnt like a fire's actual condition at temperatures of $250^{\circ} \mathrm{C}$ and $400^{\circ} \mathrm{C}$. At the temperature of $250^{\circ} \mathrm{C}$, the specimens showed no significant change. Fire testing was tested on bricks with $5 \%$ and $10 \%$ CCR. The test was conducted at a percentage of $15 \%$ because the compressive strength was below $1 \mathrm{MPa}$, and the water absorption capacity of brick exceeded the permitted limit. In other words, this brick was considered a fail brick based on the composition and quality test. The effect of fire on lightweight bricks can be seen from several aspects, namely:

\section{a. Discoloration in the concrete}

At a temperature of $250^{\circ} \mathrm{C}$, the lightweight bricks started turning brown and grey. When the temperature was increased to $400^{\circ} \mathrm{C}$, the brick began to blacken, and the brick looked porous due to the damage of the cement, sand, and carbide hydration bond, and the water helping these bonds was reduced.

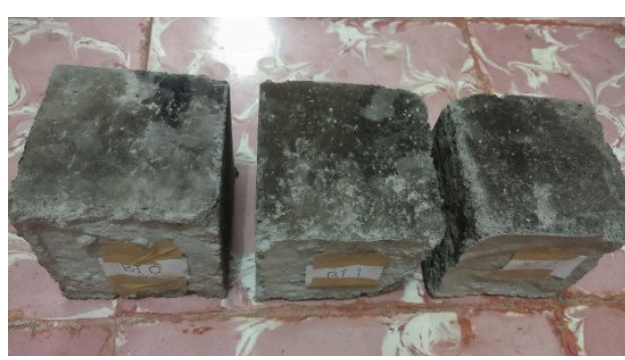

at $250^{\circ} \mathrm{C}$

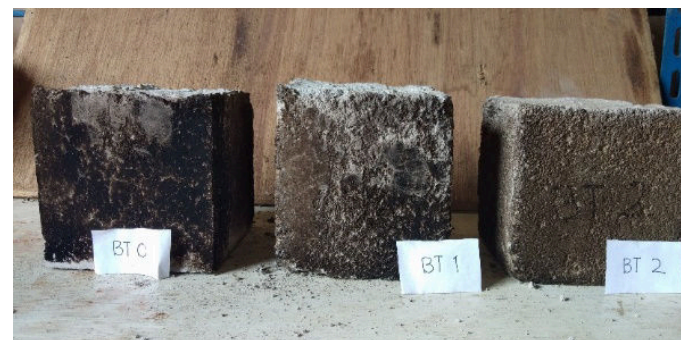

at $400^{\circ} \mathrm{C}$

Figure 5. The discoloration of lightweight bricks at various combustion temperatures. 


\section{b. Spalling and crazing on the concrete}

Spalling is a symptom of removing a portion of a concrete surface in the form of a thin layer of several centimeters [22]. Crazing is a symptom of breaking on a concrete surface (such as an eggshell rupture). At the temperature of $250^{\circ} \mathrm{C}$, spalling was seen, but no crazing was found. However, crazing occurred at $400^{\circ} \mathrm{C}$, indicated by the brick flakes left in the furnace.

\section{c. Cracking}

At the temperature of $250^{\circ} \mathrm{C}$, the cracks occurred at the brick $0 \%$, and $5 \%$ carbide was hair cracking (micro-cracking). In the composition of $0 \%$ carbide, not only hair cracking but also exfoliation at the top layer of brick occurred. The increased temperature enhanced the cracks, and it was visually apparent [23] [24]. Thus, it can be concluded that the concentration of carbide in lightweight bricks could not prevent cracking.

\subsection{Microstructural analysis}

The optical microscopy study was carried on the specimens at different temperatures and compared to the ambient temperature, as presented in Fig. 6 . At the combustion temperature of $250^{\circ} \mathrm{C}$, the lightweight bricks sustained an increasing temperature during the heating. Besides, the water in the pores and capillaries in the lightweight bricks also evaporated. The compressive strength had also started to decrease.

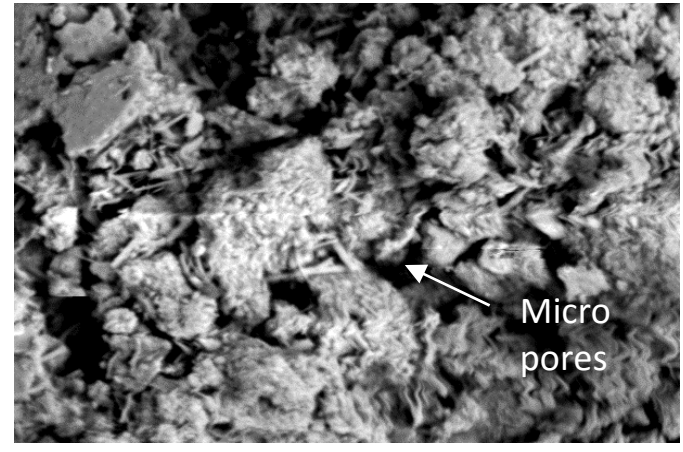

at ambient temperature

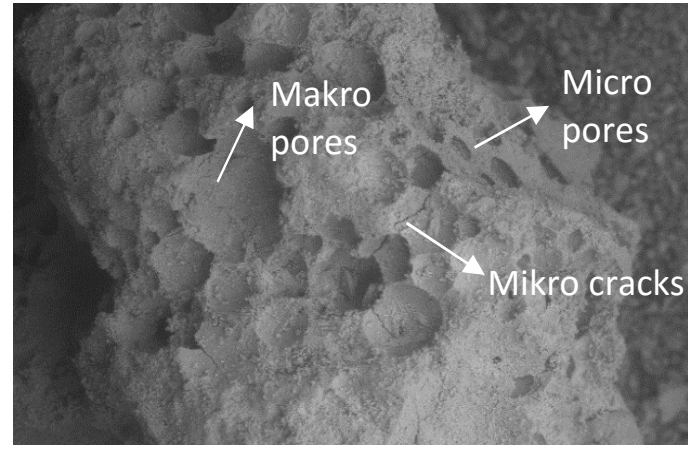

at $250^{\circ} \mathrm{C}$

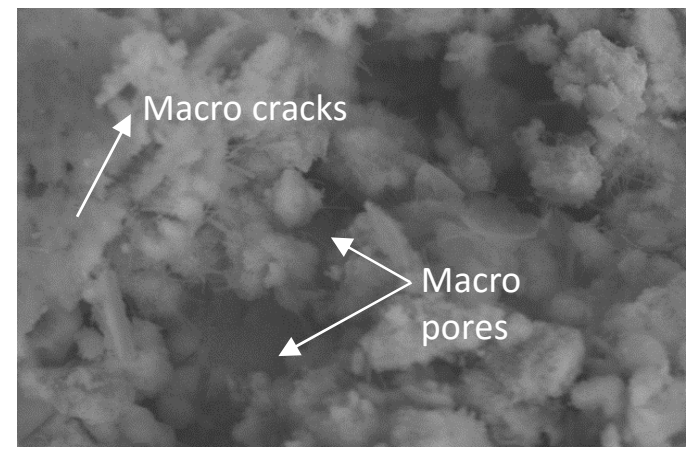

at $400^{\circ} \mathrm{C}$

Figure 6. Optical microscopy of lightweight bricks without the addition of CCR 


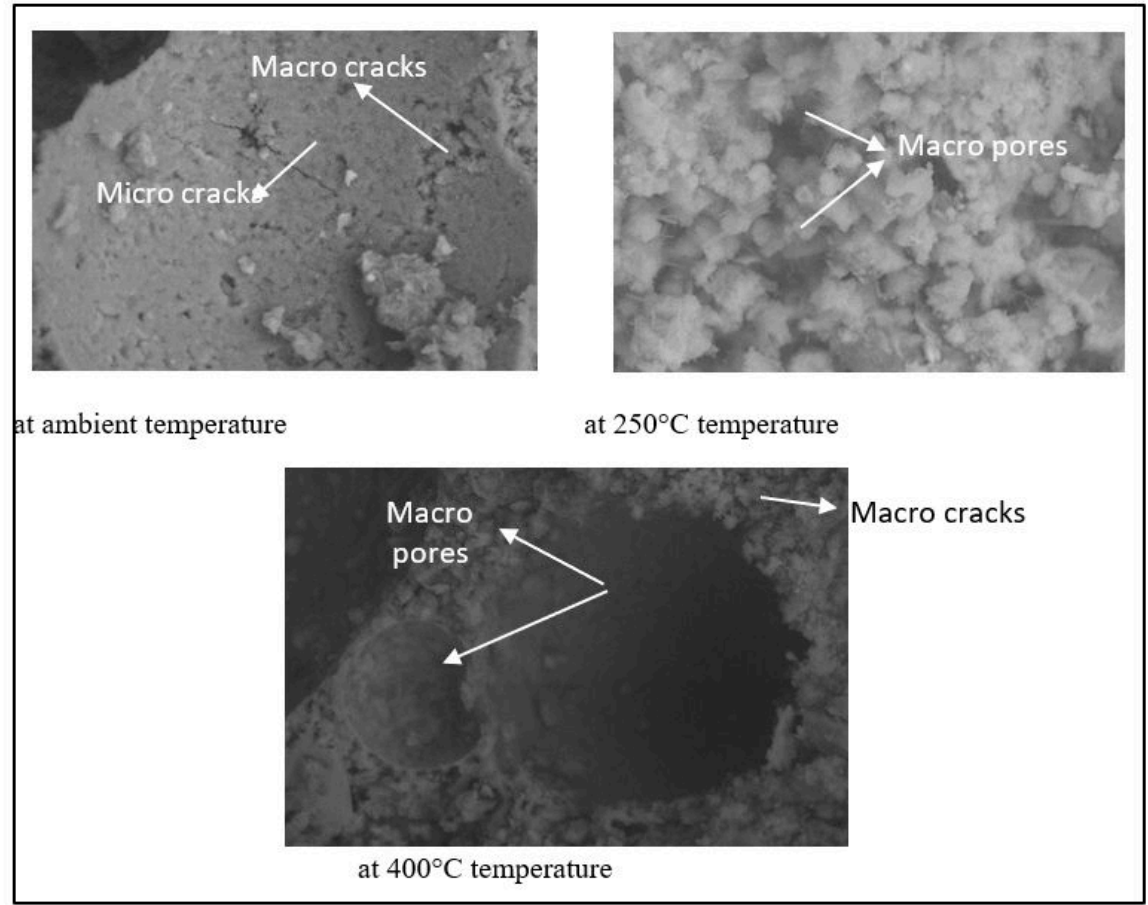

Figure 7. Optical microscopy of lightweight bricks with 5\% CCR

\section{FTIR analysis}

Fig. 8 displays the FTIR method, while Table 5 presents its result. Fig. 8 shows the analysis results of the chemical bond changes in the lightweight bricks with the addition of foaming agent $/ \mathrm{H}_{2} \mathrm{O}_{2}$. The peaks in the area around $3408.22 \mathrm{~cm}^{-1}$ and $1639.49 \mathrm{~cm}^{-1}$ indicated the presence of $-\mathrm{OH}$ stretching vibration and $\mathrm{H}-\mathrm{O}-\mathrm{H}$ bending vibration of water molecules [25]. This band showed that there were water molecules on the surface or were trapped in cavities in the lightweight brick structures. Therefore, it can be concluded that the highest compressive strength was achieved at the $5 \%$ carbide composition; because the amount of $\mathrm{H}_{2} \mathrm{O}_{2}$ used reacted with $\mathrm{CaO}$ and thus $\mathrm{H}_{2} \mathrm{O}$, as the result of decomposition of $\mathrm{H}_{2} \mathrm{O}_{2}$, was reduced.

Table 5. Interpretation of IR-spectra at temperatures of $250^{\circ} \mathrm{C}$ and $400^{\circ} \mathrm{C}$

\begin{tabular}{|c|c|c|c|c|}
\hline \multicolumn{4}{|c|}{ Wavenumber $\mathbf{c m}^{-1}$} & \multirow[t]{3}{*}{ Functional groups } \\
\hline \multicolumn{2}{|c|}{ 0\% CCR } & \multicolumn{2}{|c|}{$5 \%$ CCR } & \\
\hline $250^{\circ} \mathrm{C}$ temp. & $400^{\circ} \mathrm{C}$ temp. & $250^{\circ} \mathrm{C}$ temp. & $400^{\circ} \mathrm{C}$ temp. & \\
\hline 1458.18 & 1467.83 & 1467.83 & 1454.33 & O-C-O Stretching \\
\hline 1639.49 & 1629.85 & 1627.92 & 1629.85 & $\begin{array}{l}\mathrm{H}-\mathrm{O}-\mathrm{H} \text { Bending from } \\
\text { water molecules } \\
\mathrm{C}-\mathrm{H} \text { Stretching }\end{array}$ \\
\hline 2972.31 & 2974.23 & 2970.38 & 2978.09 & O-H Stretching \\
\hline 3408.22 & 3441.01 & 3419.79 & 3427.51 & Hydrogen bonded \\
\hline
\end{tabular}




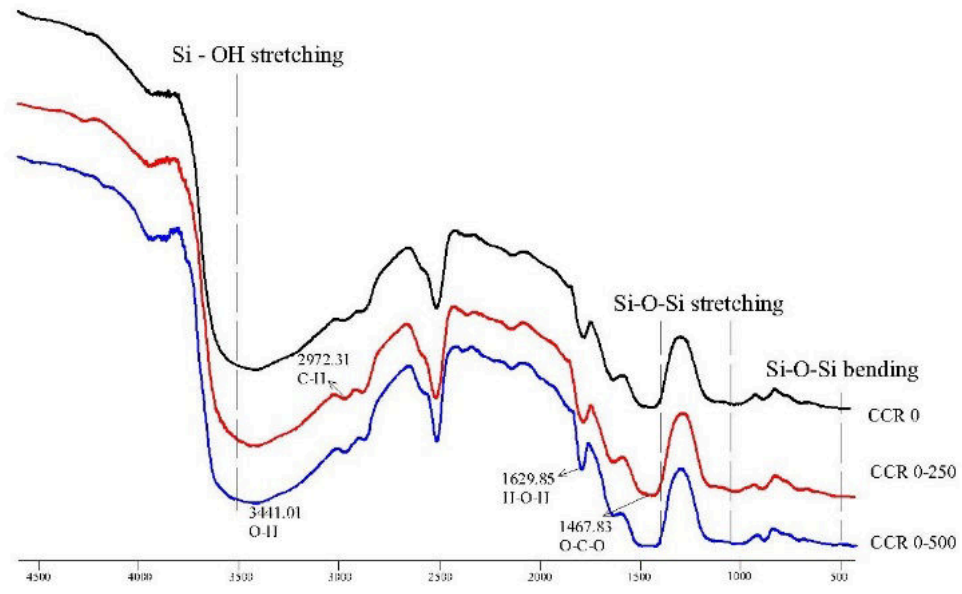

Figure 8. The result of IR-Spectra at $0 \% \mathrm{CCR}$

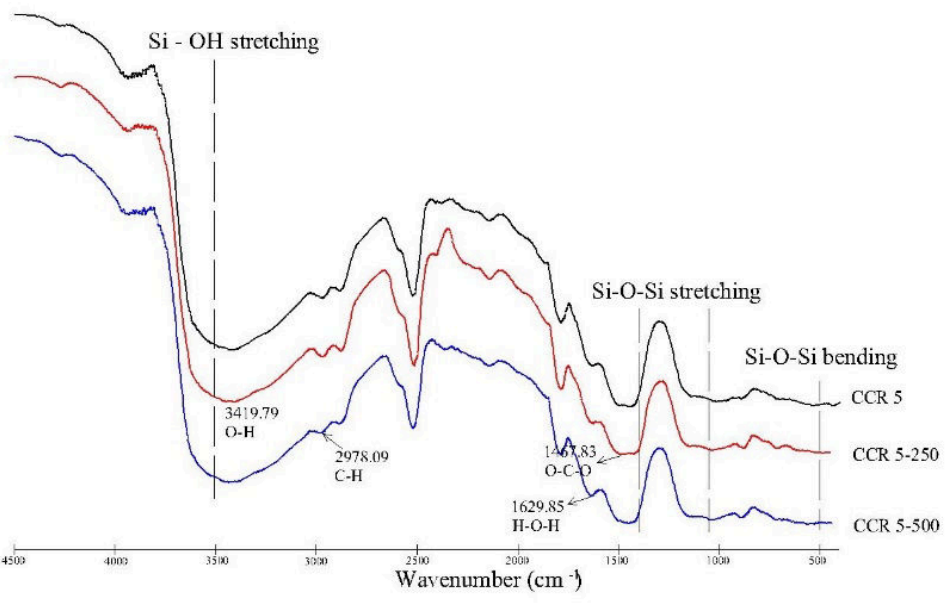

Figure 9. The result of IR-Spectra at 5\% CCR

\section{Conclusion}

1. There was an increase in the compressive strength at 5\% CCR. In contrast, the compressive strength decreased at $10 \%$ CCR or higher

2. The result of IR-spectra showed the water molecules in the lightweight brick cavities. The highest compressive strength was reached at the composition of $5 \%$ carbide because the amount of $\mathrm{H}_{2} \mathrm{O}_{2}$ used to react with $\mathrm{CaO}$ from calcium carbide residue.

3. At the high temperature, the decomposition of calcium and silica occurred. Hence, there was a very drastic decrease in the compressive strength of concrete. The lightweight bricks could still be used with the addition of $5 \%$ of calcium carbide residue at $400^{\circ} \mathrm{C}$. However, at the temperature above $400^{\circ} \mathrm{C}$, the lightweight bricks will fail.

4. The addition of carbide at the lightweight bricks was only allowed by $5 \%$.

5. Visual observations after fire exposure was discoloring, spalling, crazing, and cracking. 


\section{Acknowledgement}

The authors would thank the Directorate of Research and Community Service, Directorate General of Research and Development, Ministry of Research, Technology, and Higher Education of Indonesia following the research contract Number: 119/SP2H/LT/DRPM/2019.

\section{References}

[1] S. P. Teong and Y. Zhang, "Calcium carbide and its recent advances in biomass conversion," $J$. Bioresour. Bioprod., vol. 5, pp. 96-100, 2020.

[2] C. Jaturapitakkul and B. Roongreung, "Cementing Material from Calcium Carbide ResidueRice Husk Ash,” J. Mater. Civ. Eng, vol. 15, p. 470-475., 2003.

[3] H. Sun et al., "Properties of Chemically Combusted Calcium Carbide Residue and Its Influence on Cement Properties," Materials (Basel)., no. 8, pp. 638-651, 2015.

[4] V. Noolu, H. Mudavath, R. J. Pillai, and S. K. Yantrapalli, "Permanent deformation behaviour of black cotton soil treated with calcium carbide residue," Constr. Build. Mater., vol. 223, pp. 441-449, 2019.

[5] U. Parlikar, P. S. Bundela, R. Baidya, and S. K. Ghosh, "Effect of Variation in the Chemical Constituents of Wastes on the Co-processing Performance of the Cement Kilns," Procedia Environ. Sci., vol. 35, pp. 506-512, Jan. 2016.

[6] A. G. Guimarães, P. Vaz-Fernandes, M. R. Ramos, and A. P. Martinho, "Co-processing of hazardous waste: The perception of workers regarding sustainability and health issues in a Brazilian cement company," J. Clean. Prod., vol. 186, pp. 313-324, Jun. 2018.

[7] V. Subathra Devi, "Durability properties of multiple blended concrete," Constr. Build. Mater., vol. 179, pp. 649-660, Aug. 2018.

[8] S. Cabral-Fonseca, J. R. Correia, J. Custódio, H. M. Silva, A. M. Machado, and J. Sousa, "Durability of FRP - concrete bonded joints in structural rehabilitation: A review," Int. J. Adhes. Adhes., vol. 83, pp. 153-167, Jun. 2018.

[9] L. T. Phan and N. J. Carino, "Fire performance of high strength concrete: research needs," $A d v$. Technol. Struct. Eng., 2000.

[10] C. Kahanji, F. Ali, A. Nadjai, and N. Alam, "Effect of curing temperature on the behaviour of UHPFRC at elevated temperatures," Constr. Build. Mater., vol. 182, pp. 670-681, 2018.

[11] C. C. Santos and J. P. C.Rodrigues, "Calcareous and granite aggregate concretes after fire," $J$. Build. Eng., vol. 8, pp. 231-242, 2016.

[12] I. N. Grubeša, B. Marković, A. Gojević, and J. Brdarić, "Effect of hemp fibers on fire resistance of concrete," Constr. Build. Mater., vol. 184, pp. 473-484, 2018.

[13] ASTM C190-92, Standard Specification for Portland Cement, ASTM International, www.astm.org.

[14] D. Hu, Y. Gu, T. Liu, and L. Zhao, "Microcellular foaming of polysulfones in supercritical CO2 and the effect of co-blowing agent," J. Supercrit. Fluids, vol. 140, pp. 21-31, Oct. 2018.

[15] A. Hajimohammadi, T. Ngo, and P. Mendis, "How does aluminium foaming agent impact the geopolymer formation mechanism?," Cem. Concr. Compos., vol. 80, pp. 277-286, Jul. 2017.

[16] ASTM C67, Testing of Brick and Structural Clay Tile, ASTM International, www.astm.org.

[17] K. S. D, and A. K. Vyas, "Impact of fire on mecanical properties of concrete containing marble waste," J. King Saud Univ. Sci., vol. 31, no. 1, pp. 42-51, 2019.

[18] V. Jocius and G. Skripkiūnas, "The Mechanism of Disintegration of Cement Concrete at High Temperatures," Constr. Sci., vol. 18, pp. 4-9, 2016.

[19] N. Khurram, K. Khan, M. U. Saleem, M. N. Amin, and U. Akmal, "Effect of Elevated Temperatures on Mortar with NaturallyOccurring Volcanic Ash and Its Blend withElectric Arc Furnace Slag," Adv. Mater. Sci. Eng., 2018.

[20] L. Li, P. Jia, J. Dong, L. Shi, G. Zhang, and Q. Wang, "Effects of cement dosage and cooling regimes on the compressive strength of concrete after post-fire-curing from $800{ }^{\circ} \mathrm{C}, "$ Constr. Build. Mater., vol. 142, pp. 208-220, 2017. 
[21] E. DestaShumuye, J. Zhao, and Z. Wang, "Effect of fire exposure on physico-mechanical and microstructural properties of concrete containing high volume slag cement," Constr. Build. Mater., vol. 213, pp. 447-458, 2019.

[22] P. Zhu, X. Xu, H. Liu, S. Liu, C. Chen, and Z. Jia, "Tunnel fire resistance of self-compacting concrete coated with $\mathrm{SiO} 2$ aerogel cement paste under 2.5 h HC fire loading," Constr. Build. Mater., vol. 239, pp. 1-9, 2019.

[23] M. Ozawa, S. Uchida, T. Kamada, and H. Morimoto, "Study of mechanisms of explosive spalling in high-strength concrete at high temperatures using acoustic emission," Constr. Build. Mater., vol. 37, pp. 621-628, 2012.

[24] M. Szelag, "Evaluation of cracking patterns of cement paste containing polypropylene fibers," Compos. Struct., vol. 220, pp. 402-411, 2019.

[25] S. Zhang, R. Dong, M. Wang, W. Jia, and Z. Lu, "Synthesis mechanisms on waste poplar fiber lightweight biomass bricks," J. Clean. Prod., vol. 246, 2020. 